\title{
Коэффициенты умножения фотоносителей в лавинных гетерофотодидах с разделенными областями поглощения и умножения
}

\author{
В.А.Холоднов ${ }^{1,2,3,4)}$, И.Д. Бурлаков ${ }^{1,2)}$, А.К.Ильясов ${ }^{1)}$ \\ ${ }^{1}$ АО «НПО «Орион», Москва, 111538, ул. Косинская, 9 \\ ${ }^{2}$ МИРЭА - Российский технологический университет, Москва, 119454, проспект Вернадского, 78 \\ ${ }^{3}$ Институт радиотехники и электроники им.В.А. Котельникова РАН, Москва, 125009, \\ ул. Моховая 11, корп.7 \\ ${ }^{4}$ МФТИ, Москва, 117303, ул. Керченская, д. 1A, корп. 1 \\ тел:+7 (916) 189-11-28, эл. почта: vkholodnov@mail.ru
}

DOI 10.34077/RCSP2019-49

Двойные $p-n$ гетероструктуры (ГС) для лавинных фотодиодов (ЛФД) представляют собой ГС $p_{w g}^{+}-n_{w g}-n_{n g}-n_{w g}^{+}$(рис.1) или $n_{w g}^{+}-p_{w g}-p_{n g}-p_{w g}^{+}$типов. Такие ГС на основе прямозонных полупроводников позволяют создавать высокоэффективные лавинные гетерофотодиоды (ЛГФД) с разделенными областями поглощения и умножения (РОПУ) [1-3]. Для достижения высоких характеристик ЛГФД параметры ГС должны быть такими, чтобы в рабочем режиме область

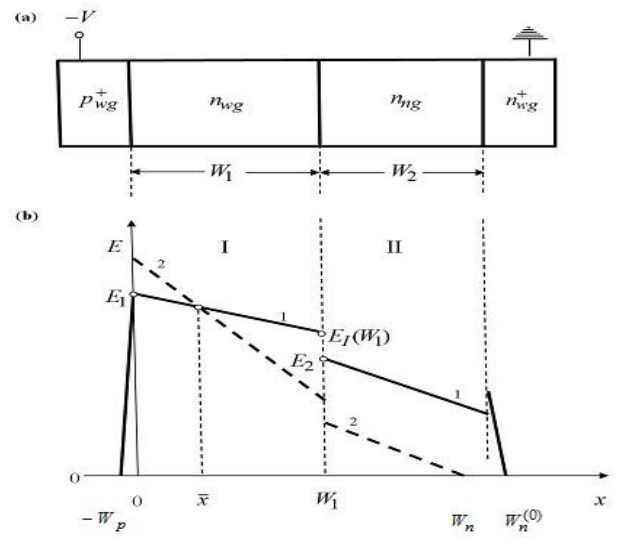

Рис. 1 Схема ЛГФД на основе $p_{w g}^{+}-n_{w g}-n_{n g}-n_{w g}^{+} \quad$ гетероструктуры (а) и распределение напряженности электрического поля в ней при напряжениях лавинного пробоя (b). Значение концентраций для кривой $1-N_{1}=N_{1}^{(0)}, 2-N_{1}>N_{1}^{(0)}$. ( $w g$ - "широкозонный").

Для гомогенных структур соответствующие выражения получены в работе [5], а для ЛГФД с РОПУ таких выражений до сих пор практически нет. В тоже время они нужны для физического проектирования ЛГФД с РОПУ. Определению искомых зависимостей и посвящен данный доклад.

\section{Литература}

[1] В.А. Холоднов. Оптимальные параметры гетероструктуры порогового лавинного фотодиода с разделенными областями поглощения и умножения. Оптический журнал. 1996. № 6. с.42-48

[2] И.Д. Бурлаков, А.М. Филачев, В.А. Холоднов Аналитическое описание характеристик лавинных фотодиодов (части I и II). Успехи прикладной физики, 2016. т. 4, № 1 и №2.

[3] С. М Зи. Физика полупроводниковых приборов. М.: Мир, 1984. Кн. 1, 455 с.; Кн. 2, 455 с.; Sze

S.M., Ng Kwok K. Physics of Semiconductor Devices. Wiley, 2007.

[4] В.А. Холоднов. О возможной связи между коэффициентами ударной ионизации электронов и дырок в полупроводниках. Письма в ЖТФ. 1988 г., Т. 14, 6, стр. 551 - 556.

[5] В.А. Холоднов. Коэффициенты лавинного размножения носителей в p-n структурах. Физика и техника полупроводников, 1996. т. 30, № 6. 